Article

\title{
Cross-Scale Linkages of Centralized Electricity Generation: Geothermal Development and Investor-Community Relations in Kenya
}

\author{
Britta Klagge ${ }^{1, *}$, Clemens Greiner ${ }^{2}$, David Greven ${ }^{3}$ and Chigozie Nweke-Eze ${ }^{1}$ \\ ${ }^{1}$ Department of Geography, University of Bonn, 53115 Bonn, Germany; E-Mail: klagge@uni-bonn.de (B.K.), \\ cne@uni-bonn.de (C.N-E.) \\ 2 Global South Studies Center, University of Cologne, 50931 Cologne, Germany; E-Mail: clemens.greiner@uni-koeln.de \\ ${ }^{3}$ Department of Social and Cultural Anthropology, University of Cologne, 50923 Cologne, Germany; \\ E-Mail: david.greven@uni-koeln.de \\ * Corresponding author
}

Submitted: 3 March 2020 | Accepted: 13 April 2020 | Published: 11 September 2020

\begin{abstract}
Based on a study of Kenya's geothermal-energy development in Baringo-Silali, we explore how and with whom government actors and local communities in rural and peripheral areas interact when planning and implementing large-scale power plants. Starting from a comparison of decentralized and centralized energy systems, we demonstrate that the development of this large-scale infrastructure project and the associated investor-community relations are governed by various cross-scale linkages. To this end, we adapt the concept of cross-scale linkages from the literature on natural-resource governance to explore actors, rules, and practices at local, regional, national, and international levels.
\end{abstract}

\section{Keywords}

Baringo; centralized electricity generation; corporate social responsibility; cross-scale linkages; geothermal development; governance; infrastructure; investor-community relations; Kenya

\section{Issue}

This article is part of the issue "Politics and (Self-)Organisation of Electricity System Transitions in a Global North-South Perspective" edited by Eberhard Rothfuß (University of Bayreuth, Germany) and Festus Boamah (University of Bayreuth, Germany).

(C) 2020 by the authors; licensee Cogitatio (Lisbon, Portugal). This article is licensed under a Creative Commons Attribution 4.0 International License (CC BY).

\section{Introduction}

Centralized electricity generation, with large-scale power plants feeding into national grids, is mainly associated with top-down planning, centralized control and negative, often unsustainable local impacts at the generation facilities' sites. In this contribution, we question this dominant narrative. We argue that cross-scale linkages in the implementation and governance of large-scale electricity generation and associated investor-community relations need to be taken into account in order to understand the local impacts of centralized energy systems. Based on preliminary results from an ongoing qualitative study of geothermal-energy development in Kenya's semi-arid north, we show that there are various cross- scale linkages at work that govern the relations between local, county, and national, as well as international actors, rules, and institutions. In our article, we will explore how different types of cross-scale linkages shape the implementation and governance of geothermal development and what potential for local development they (might) entail. The expansion of geothermal-energy provision in Kenya provides an interesting case to study such linkages in centralized electricity generation because it has become the most important source of gridconnected electricity in the country and has a great deal of potential. It is, therefore, one of the main pillars of Kenya's ambitious development strategy, Vision 2030, with far-reaching implications for economic and social development in the country's (semi-)arid and periph- 
eral North where future geothermal development will take place.

Our approach is inspired by recent research on large infrastructure projects which demonstrates that such projects are the result of combining technology with diverse actors, rules, and practices (Harvey, Jensen, \& Morita, 2017; Sovacool \& Cooper, 2013). Such complex, multilayered, and heterogeneous structures do not follow clear plans and cannot be implemented and governed in a straight-forward and top-down manner. Rather, we follow Li (2005), who, in response to Scott's (1998) seminal work on high-modernist, state-planned schemes, has argued that " $(r)$ ather than emerging fully formed from a single source, many improvement schemes are formed through an assemblage of objectives, knowledges, techniques, and practices of diverse provenance" (Li, 2005, p. 386). Infrastructure projects, such as geothermal power projects, thus can rather be understood as open-textured, large-scale social experiments (Wynne, 1988). This is not to say that power relations do not matter. Yet, to understand how power is exercised within such large-scale projects, we need to take into account the uncertainties and contingencies which can result from the multi-layered nature of their governance.

In the following, we first explore the specificities and governance implications of decentralized ver- sus centralized electricity generation. After situating geothermal development in Kenya's electricity sector and introducing our study region and methodology, we present our empirical results. This will be followed by our conclusions.

\section{Governance and Cross-Scale Linkages in Electricity Provision}

Governance structures in the electricity sector can take various forms but are usually subject to national legislation and policies. This is due not only to the fact that electricity is regarded as critical infrastructure and a prerequisite for most other activities but also to the electricity sector's network character and its socio-technical nature. These latter characteristics require coordination between different levels and places as well as between technological and social elements to function smoothly (Hughes, 1983). Nonetheless, there is a great diversity of generation technologies, grid architectures, and resulting geographies. An important distinction is made between centralized and decentralized electricity systems and generation facilities. Apart from technical and geographical differences, they also differ in their ownership and financing, thus resulting in specific governance structures and cross-scale linkages (Table 1).

Table 1. Comparison of decentralized and centralized electricity systems from a technology, geography and governance perspective for rural global south contexts.

\begin{tabular}{|c|c|c|c|}
\hline & \multicolumn{2}{|c|}{ Decentralized } & \multirow{2}{*}{$\begin{array}{l}\text { Centralized } \\
\text { (National) utility }\end{array}$} \\
\hline & Stand-alone & Mini-grid & \\
\hline Grid connection & Off-grid & Isolated (local) network & National grid \\
\hline Generation facilities' & Small-scale local & Medium-scale local & Large-scale centralized \\
\hline size and geography & $\begin{array}{l}\text { Production-site }= \\
\text { consumption-site }\end{array}$ & $\begin{array}{l}\text { Production-sites close to } \\
\text { consumption-sites }\end{array}$ & $\begin{array}{l}\text { Production-sites far away } \\
\text { from consumption-sites }\end{array}$ \\
\hline $\begin{array}{l}\text { Power-availability } \\
\text { challenges }\end{array}$ & \multicolumn{2}{|l|}{ Low electricity volumes } & Frequent outages \\
\hline $\begin{array}{l}\text { Local technology } \\
\text { challenges }\end{array}$ & \multicolumn{2}{|l|}{ Repair and maintenance } & $\begin{array}{l}\text { Maintenance, protection against } \\
\text { power theft and sabotage }\end{array}$ \\
\hline Ownership & $\begin{array}{l}\text { Private household or firm, } \\
\text { often local }\end{array}$ & $\begin{array}{l}\text { National or other } \\
\text { government and/or } \\
\text { private firm }\end{array}$ & $\begin{array}{l}\text { National providers (plus } \\
\text { independent power } \\
\text { producers [IPPs]) }\end{array}$ \\
\hline Financing & $\begin{array}{l}\text { Owners, often with } \\
\text { international donor/ } \\
\text { Development Finance } \\
\text { Institution (DFI) and/or } \\
\text { national-state support }\end{array}$ & $\begin{array}{l}\text { Owners, often with } \\
\text { international donor/ DFI } \\
\text { and/or national-state } \\
\text { support }\end{array}$ & $\begin{array}{l}\text { The national state, local- } \\
\text { connection charge often paid } \\
\text { for by the consumer, } \\
\text { sometimes international } \\
\text { DFI support }\end{array}$ \\
\hline Local governance dimension & \multicolumn{2}{|c|}{$\begin{array}{l}\text { Strong, with cross-scale linkages to national and } \\
\text { international actors }\end{array}$} & $\begin{array}{l}\text { Small, apart from (possibly) } \\
\text { at power-generation sites }\end{array}$ \\
\hline
\end{tabular}

Source: Authors' own compilation based on various sources. 
In much of the Global South, public electrical infrastructure has until recently mainly been provided in the form of large-scale generation facilities, mostly hydroand coal-powered, feeding into national grids. Rural and peripheral regions, however, are often not connected to such centralized infrastructure, and electricity can only be provided in a decentralized way. This includes smallscale off-grid electricity infrastructure such as diesel generators and, more recently, solar home systems as well as mini-grids, which have emerged as another alternative in recent years (Alstone, Gershenson, \& Kammen, 2015), often donor-driven and provided by non-state actors. Because of the close connection between powergenerating facilities and consumers, as well as its flexibility and scalability, decentralized electricity provision is often regarded as advantageous from both a localdevelopment perspective as well as in terms of sustainability (Boliko \& lalnazov, 2019; Bouffard \& Kirschen, 2008; Kirubi, Jacobson, Kammen, \& Mills, 2009). In contrast, centralized electricity generation is mainly associated with inflexibility, centralized control, and negative local impacts at the power-plant locations (Alanne \& Saari, 2006; Boamah, 2020). These often include environmental damage, large-scale population resettlement and the general deterioration of local livelihoods. As connecting people to national grids in peripheral areas is expensive, large-scale power plants might not even provide electricity access to neighbouring, hitherto unserved local communities (Alstone et al., 2015). In sum, decentralized electricity systems are regarded as supporting local development, whereas centralized electricity-generation facilities are not, or are thought to do so to a much lesser degree.

While the governance of decentralized electricity systems has a strong local dimension, the governance of centralized electricity generation is overwhelmingly shaped by cross-scale interactions. Power plants are usually implemented and operated from a distance either directly by national power companies or by governmentcommissioned IPPs since the electricity has to be transported via national grids to where it is required. Decisions on the location of large-scale plants follow factors such as, in the case of renewable electricity generation, the availability of natural resources (water, wind, solar radiation, geothermal reservoirs). Such power plants are therefore often located far from economic and population centers and entail cross-scale linkages in the realms of planning, development, financing, ownership, and management. These linkages encompass nationaland often also international-level investors and locallevel communities, they are complex, and bring with them challenges which need careful consideration.

\subsection{Cross-Scale Linkages and Multilevel Governance}

With reference to Berkes (2002, p. 293), we define cross-scale linkages as interactions of different actors, institutions, and rules "both horizontally (across space) and vertically (across levels of organization)." Scale chal- lenges and cross-scale linkages play an important role in the literature on human-environment relations and common-pool resources (Cash et al., 2006; Ostrom, 2005). These ideas help conceptualize cross-scale linkages in the investor-community relations of electricitygeneration facilities. Generally, addressing scale issues is seen as important for sustainable resource management (Cash et al., 2006), where top-down approaches have proved to be "too blunt and insensitive to local const[r]aints and opportunities...[whereas] bottom-up approaches....are too insensitive to the contribution of local actions to larger problems." Instead, Cash et al. (2006) propose "a middle path that addresses the complexities of multiple scales" and distinguishes between three "responses to problems of scale and cross-scale interactions: institutional interplay, co-management, and bridging organizations," all of which play a role in our case study.

Institutional interplay means the vertical interplay of governments and administrations at different levels. In Kenya, this includes, for example, royalty-sharing from natural-resource exploitation and the distribution of government functions as a result of devolution. The creation and empowerment of legislative and executive actors at the county level have increased the options for institutional interplay and, more generally, added complexity to a political system which has been characterized by corruption, patronage, and inter-ethnic competition (Mwangi, 2008). Institutional interplay can range from highly asymmetric to relatively balanced relations. The latter comes close to what Cash et al. (2006) call comanagement, i.e., "a continuum of arrangements that rely on various degrees of power- and responsibilitysharing between governments and local communities." We adapt this notion of co-management to denote cooperation between local communities and other actors, as for example in the management of water points associated with geothermal development.

The establishment of bridging organizations as the third response to scale challenges goes beyond intergovernmental or government-community activities. Bridging organizations are deliberately designed to act across (administrative) scales, thereby sidelining administrative hierarchies to some extent. They are similar to what Hooghe and Marks (2003) call Type II multilevel governance. Whereas Type I multilevel governance refers to general-purpose jurisdiction at a limited number of levels as part of a systemwide architecture-thus reflecting traditional government levels and interactions-Type II multilevel governance is characterized by task-specific jurisdiction with intersecting memberships. Its main advantage is that it can respond flexibly to newly emerging or changing stakeholder preferences. In our case study, the Geothermal Development Corporation (GDC) acts as such a bridging organization.

The three forms of multilevel governance organization revolve mainly around the interaction of administrative government levels within a country. However, the role of international actors and communities, as 
both active participants in and detractors of such governance, needs closer consideration. The concept of context shaping put forward by Hay (1997) helps better understand their roles in the multilevel governance of largescale power generation projects. We will demonstrate later that local communities have-to some extentthe power to re-define what is possible for the investor and "alter the parameters of subsequent action" (Hay, 1997, p. 51).

\section{Study Context and Methodology}

Kenya, with its ambition to achieve universal electricity access by 2022, now pursues a national-government strategy to combine centralized and decentralized electricity provision. While, on the one hand, grid access is to be expanded along and through extending and densifying existing grids, the remaining areas, on the other hand, are supported through the development of offgrid and mini-grid systems (Ministry of Energy [MoE], 2018). The comprehensive electrification effort is part of the Vision 2030, which aspires to make Kenya a middleincome industrializing country by 2030 (Government of Kenya [GoK], 2007). It also aims to improve livelihoods in hitherto unserved rural and peripheral areas.

\subsection{Overview of Kenya's Power Sector and the Role of Geothermal Electricity}

The recent development in the Kenyan power sector is characterized by an impressive growth of gridconnected electricity generation and a transition from hydropower and fossil-fuel to geothermal electricity (Table 2). Geothermal resources have been used for electricity generation in Kenya since 1981 when the first geothermal power station started operation south of Lake Naivasha. Today, there are four geothermal power stations in operation (Olkaria I-IV), all located in Hells Gate National Park, which was created in 1984 (Hughes \& Rogei, 2020). Two more are under construction (Olkaria V) or planned (Olkaria VI). The development of Olkaria steamfields has become infamous for the involuntary resettlement and eviction of local Maasai and other communities. Attempts at mediation have been un- satisfying so far and local activists are in contact with the World Bank, the major international funder, regarding their grievances (Hughes \& Rogei, 2020; Koissaba, 2018; Schade, 2017; but also see Mariita, 2002).

The further tapping of its rich geothermal resources is Kenya's most important strategy for increasing centralized electricity generation. In 2008, the Kenyan government incorporated the GDC, a parastatal under the auspices of the MoE, to fast-track the exploitation of geothermal energy with the ambitious aim of achieving a geothermal capacity of 5,000 MW by the year 2030 (Eberhard, Gratwick, Morella, \& Antmann, 2016). The GDC was established due to the high upfront costs and risks involved in geothermal development, which makes it unattractive to private investors (Klagge \& Nweke-Eze, 2020). These include the costs for establishing the necessary ancillary infrastructure, such as roads and water provision, and the risk of not reaching the anticipated steam capacity. The GDC covers these risks and costs, supported by loans and grants from foreign donors and development partners, with the aim of selling the steam generated either to the national power-generation company KenGen or to private IPPs.

The GDC has taken responsibility for the development of geothermal energy production from Lake Naivasha northward along the Rift Valley, starting in 2011 with Menengai, a caldera bordering the northern side of the city of Nakuru (Figure 1). It has an estimated total potential of 1,600 MW, of which $170 \mathrm{MW}$ are realized (GDC, n.d.a). Currently, the so-called Baringo-Silali Block with an estimated total potential of 3,000 MW is being developed. The first three phases will develop $100 \mathrm{MW}$ each with funding from the GoK and the German Development Bank (KfW; GDC, n.d.b). Detailed surface studies were concluded in 2013 at three exploration sites-Korosi, Paka, and Silali. In December 2018, drilling started after a first rig was transported from Menengai to Baringo-Silali, and in September 2019 steam was hit in Paka (GDC, 2019).

\subsection{Study Region and Methodology}

Baringo is part of Kenya's Central Rift Valley. It is a semiarid acacia-bush savanna with high inter-annual varia-

Table 2. Grid-connected electricity generation by sources in Kenya in 1995, 2005, and 2015.

\begin{tabular}{lrrrrrr}
\hline & \multicolumn{2}{c}{1995} & \multicolumn{2}{c}{2005} & \multicolumn{2}{c}{2015} \\
\cline { 2 - 7 } Energy sources & GWh & \multicolumn{3}{c}{ GWh } & \multicolumn{1}{c}{ GWh } \\
\hline Oil & 416 & $10.2 \%$ & 1645 & $28.3 \%$ & 1206 & $12.4 \%$ \\
Biofuels & 122 & $3.0 \%$ & 131 & $2.3 \%$ & 122 & $1.3 \%$ \\
Hydro & 3163 & $77.3 \%$ & 3026 & $52.0 \%$ & 3787 & $39.1 \%$ \\
Geothermal & 390 & $9.5 \%$ & 1003 & $17.2 \%$ & 4479 & $46.2 \%$ \\
Solar PV & & & 13 & $0.2 \%$ & 37 & $0.4 \%$ \\
Wind & & & & $100 \%$ & 57 & $0.6 \%$ \\
Total & 4091 & $100 \%$ & 5818 & $10 \% 8$ & $100 \%$ \\
\hline
\end{tabular}

Source: International Energy Agency (2020). 


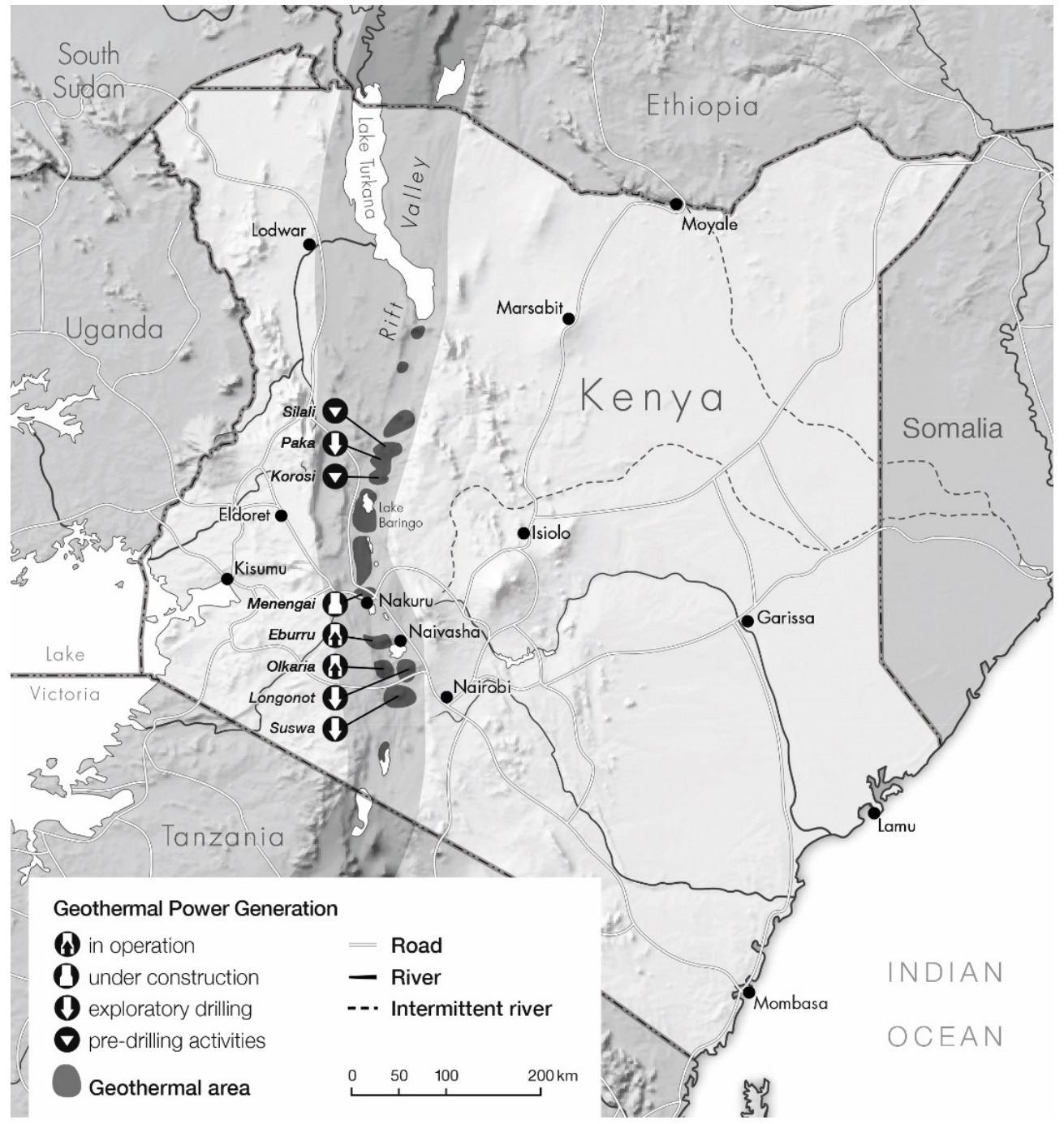

Figure 1. Map of geothermal areas and power generation in Kenya. Source: Authors' illustration based on interview information and Mangi (2017, p. 4).

tions in rainfall and recurrent droughts. Lake Baringo, one of two freshwater lakes in the Rift Valley, is the only perennial water source. The largest part of the Baringo-Silali complex falls into Baringo County, which is inhabited almost exclusively by Nilotic-speaking Pokot. The Pokot in Baringo have practiced semi-nomadic pastoralism for much of the past 200 years and constituted a close-knit, egalitarian, and rather inward-looking community (Anderson \& Bollig, 2016; Bollig, 2016). Since about the 2000s, however, an increasing number of households have started to diversify their livelihoods, settling down more permanently and starting rain-fed cultivation. This has caused conflict regarding ownership and usage of the land, which had been almost exclusively used as communal rangelands before, as well as increasing fragmentation of the Pokot into territoriallybased communities (Greiner, 2017). The area is remote and has been marginalized in the past with high illiteracy rates (Baringo County Government, 2014), a poor road network, and strong population growth rates. Frequent outbreaks of violence and cattle raids between the
Pokot and their neighbours have worsened the situation (Greiner, 2013).

Our findings on geothermal development in Baringo are based on ongoing ethnographic fieldwork in the area (Bollig, Greiner, \& Österle, 2014; Greiner, 2020), which includes a multitude of informal interviews with community members and representatives conducted between 2009 and 2020. These are complemented by expert interviews, the analysis of relevant investment and policy documents, and site visits to the Baringo-Silali, Menengai, and Olkaria geothermal fields (2017-2020). We conducted interviews with key experts involved in the development of geothermal energy in Kenya, working at different government levels (MoE, National Treasury, County Commission, County Government), in energy-related and other state agencies (Energy Regulatory Commission [ERC], GDC, KenGen, National Land Commission [NLC]), and in DFls (African Development Bank, $\mathrm{KfW}$ ). As many of the interviews were granted on the condition of anonymity, we do not provide further details of the interviewees. 


\section{Results}

In the following paragraphs, we will focus on the actors, rules, and practices in the context of the implementation of infrastructure for geothermal development. Starting with the parastatal GDC and other important actors, we then highlight the most important formal rules and regulations that govern the local and community aspects of infrastructure implementation. Following this, we illustrate some of the practices and institutions that have emerged in the negotiations of the investor (GDC), local communities, and other stakeholders with a focus on corporate social responsibility (CSR) measures, community responses, and local practices.

\subsection{The GDC as a Bridging Organization, Its Partners, and Stakeholders}

The most important actor in geothermal development in Baringo-Silali is the GDC, headquartered in Nairobi. Incorporated by the GoK in 2008, the GDC performs the function of a bridging organization. Its tasks include exploration and drilling in promising geothermal sites, development and management of steamfields, associated legal processes, and community engagement. The GDC has become a specialist in these activities-even acting as an advisor in neighbouring countries-and involves various partners and stakeholders (Table 3 ). Partners and stakeholders include public-government actors at the national level, such as ministries and agencies. Private national- or even international-level actors include consultants, contractors and, at a later stage, power-plant developers and operators.

Most important for cross-scale linkages are international as well as local- and county-level actors and stakeholders. International actors include financing in- stitutions, in Baringo the $\mathrm{KfW}$ and the GRMF of the African Union Commission (Klagge \& Nweke-Eze, 2020). While the financing contract is negotiated and administered by the MoE and the Treasury on behalf of the GDC, KfW is also involved in the project itself and has its own guidelines on environmental, social, and climate standards (KfW Development Bank, 2019), which follow World Bank and International Finance Corporation (IFC; IFC as part of the World Bank Group) standards and which the GDC must meet to continue to receive funding.

Interestingly, there are, to our knowledge as of March 2020, no international, national, or local NGOs or CSOs (Civil Society Organizations) active in Baringo. This stands in contrast to other large renewable-energy projects in the wider region, such as the Bujagali Hydropower project in Uganda (Linaweaver, 2003), Lake Turkana Wind Park in northern Kenya (Enns, 2016), and the geothermal development in Naivasha in southern Kenya (Hughes \& Rogei, 2020). The reason for this is related to the low level of international investment until now (Klagge \& NwekeEze, 2020), the history of the Pokot people, and the marginalization of the region (see Section 3.2). The representation and inclusion of local and community interests in the Baringo geothermal development, therefore, hinges on formal and informal engagement activities by the GDC and government actors as well as on community responses and local practices beyond these activities.

At the regional and local level, the county government and the communities have to grant land-access rights and participate in the ESIA. The local population is involved in community engagement as part of ESIA and the development and implementation of related CSR measures. They also provide labour, mostly unskilled and casual, to GDC and its contractors. This happened primarily in the early implementation stage through locallybased SACCOs as important intermediaries between the

Table 3. GDC tasks, important partners, and stakeholders.

\begin{tabular}{ll}
\hline Tasks & Important partners and stakeholders \\
\hline Sensitization of local communities and & Local populations, community representatives (especially elders), Savings and \\
management of community relations & Credit Cooperatives (SACCOs)
\end{tabular}

Obtain land-access rights

Environmental and Social Impact Assessment (ESIA)

Other regulatory issues

Financing

Exploration and drilling
County governments, local communities, and (other) landowners, NLC

National Environment Management Authority (NEMA), local communities, county governments, DFIs, consultancies

Energy and Petroleum Regulatory Authority (EPRA, successor of ERC), MoE, other ministries plus various others

MoE, Ministry of Finance/National Treasury, external funders (in Baringo-Silali: $\mathrm{KfW}$, Geothermal Risk Mitigation Facility [GRMF])

Consultants (geology, engineering), contractors (construction, catering, guarding), SACCOs, and local labour

Power-plant developers and operators (KenGen, IPPs)

Management of steamfields

Source: Authors' own compilation. 
GDC and contractors on the one hand and the local population on the other hand. Furthermore, once electricity is generated, the county and the communities will receive a share of the royalties according to the new Energy Act (from 2019), which stipulates that $75 \%$ remain with the national government, while $20 \%$ and $5 \%$ go to the county and the community respectively, the latter to "be payable through a trust fund managed by a board of trustees established by the local community" (Republic of Kenya, 2019, p. 69). So far, the communities are represented by their informally constituted elders, who frequently meet in the council of elders. These community representatives act as a major contact point for the GDC and the county government and, in turn, communicate community grievances to the GDC.

The importance of interaction with local- and countylevel actors is highlighted by the fact that the GDC has community-relations officers and a regional administrator for Baringo-Silali. Furthermore, the GDC's departments for Environment Management and Community Engagement are located in Nakuru, close to both Menengai and Baringo-Silali (Figure 1). The rationale behind this is that the GDC staff members in these departments are able to reach the project sites more easily. In contrast, corporate planning, financing, and dealing with national and international partners are done from the headquarters in Nairobi. The relationships between the GDC and its partners and stakeholders are mainly governed by national legislation or regulations.

\subsection{Formal Rules and Regulations Governing GDC's Activities in Baringo}

The geothermal development process in Baringo is subject to a variety of laws and other types of regulation, which govern important aspects of investor-community relations such as land access, environmental issues, and community engagement. Negotiation over these issues takes place between different actors, representing an interplay among different levels of formal administrations and agencies as well as between formal and traditional authorities.

\subsubsection{Access to Land}

Land acquisitions for geothermal operations are complex. To access the resource, pastureland had to be provided for establishing local infrastructure including well pads, water systems, storage facilities and workers' camps. Ownership- and use-rights had to be negotiated with the traditional authorities and in some cases private owners. The construction of the local road network was started 2014 by a local contractor, followed by the levelling of terrain for the well pads, i.e., the actual drilling sites. During all these construction processes, the GDC and contractors were involved in negotiations with community representatives. If, for example, livestock trails were affected by road construction, or the levelling of a well pad required cutting down ritual trees, a negotiation between the parties was facilitated by the GDC community-relations officers to explore changes in route or possible compensation.

Land acquisition happened in a phase of profound legal transformation. The Community Land Act only became effective in 2016. With this act, former community trust land was replaced by community land, which is adjudicated to the respective community. The Community Land Act protects the community land rights, defines the role of counties in land matters, and provides rules for compensation in cases of compulsory acquisition by the state. The process of land adjudication, however, whereby local communities have to be registered as rightful owners of the land, had not yet occurred in Paka, Silali, or Korosi when the GDC started their operations. In this opaque situation, the GDC proceeded to negotiate only where necessary on an informal basis with community representatives and postponed such negotiations where possible.

\subsubsection{ESIA and Community Engagement}

An ESIA, officially referred to as an Environmental Impact Assessment (EIA), is:

[A] critical examination of the effects of a project on the environment. An EIA identifies both negative and positive impacts of any development activity or project, how it affects people, their property and the environment. EIA also identifies measures to mitigate the negative impacts, while maximizing on the positive ones. (NEMA, 2020)

The Environmental Management and Co-Ordination Act (from 1999, amended in 2015) regulates that geothermal-energy projects have to undergo EIAs and that there are additional Environmental (Impact Assessment and Audit) Regulations on its scope and procedure, with NEMA as the supervising government agency. Viewed in the light of multilevel governance, ESIA represents an institution imposed on project developers in a top-down manner, thereby constituting cross-scale linkages and requiring institutional interplay of actors at different levels (Table 3). In Baringo-Silali, this includes KfW as a major international funder with its own guidelines, and we were told that the ESIA for Baringo-Silali had to be updated in 2016-2017 due to request by KfW. As the ESIA for Baringo-Silali has not been made available so far, the following information on community-related activities is drawn from other sources, mainly our interview material.

The first ESIA report was submitted to NEMA in 2012 and approved in 2013, which marked the official start of the project. It was followed by the acquisition of land, the construction of roads and other facilities as well as the establishment of a community-engagement framework, which includes, according to GDC representatives, 
12 community public meetings per year as open forums where usually around 50-150 people participate. The GDC representatives both in Nakuru and Nairobi regard community engagement as an important and critical part of GDC activities. They say it is important to involve local people from the early stage and step-by-step so that everybody is carried along. This is reiterated by an MoE interview partner who stresses that it is the GDC's responsibility to make sure that they have the buy-in of the communities, which he sees as a critical success factor: To achieve "community buy-in," the GDC has to integrate with the communities in the project operations, ranging from providing local jobs to investing in social infrastructure. Here lies the rationale for various CSR measures implemented by the GDC. It remains unclear, however, to what extent CSR measures are (also) required by NEMA as part of the ESIA process or by $\mathrm{KfW}$ as a major international funder.

\subsection{Water Points and Other CSR Measures}

From 2016 onward, the GDC started with the construction of the water infrastructure to supply water for drilling, including water basins for contaminated water. The water is pumped at high pressure from Lake Baringo into four basins on the volcano tops. From there it is released by gravity to the drilling sites. Additionally, the GDC (2019) has started building a "robust community water supply program with 20 watering points for domestic and livestock use," which includes treatment plants to filter water for human consumption.

The 20 community water points (CWPs) are planned as freely accessible infrastructure, which-according to the NLC county coordinator for Baringo-are one form of CSR by the GDC. This view, however, is not shared by representatives of the local communities, who understand the CWPs as part and parcel of the initial agreement with the GDC. According to GDC representatives, it was community representatives who initially demanded access to water. This request was then taken up by GDC headquarters, where water provision was identified not only as major leverage to buy-in the community but also as a key development factor. This apparently convinced $\mathrm{KfW}$ to approve the water-supply program to safeguard the project in the future.

The actual sites of the CWPs were determined by the communities. To manage the CWPs, the GDC has encouraged them to form a committee for each water point. These committees are meant to regulate water access and to prevent sabotage through unplanned usage, which came to be a major problem in some areas. Since repair of leakage and damage caused by illegal tapping is carried out by the GDC or a contractor, these water point committees can be classified as institutions of co-management.

CSR-related institutions and regulations were also introduced to facilitate the recruitment and payment of the temporary workforce of the communities by the GDC and contractors. To this end, the communities were encouraged to form SACCOs to ensure fair distribution of jobs and decide on the usage of an overhead paid to the communities. Another labour-related CSR measure, not as yet realized, is an agreement between the GDC and Baringo County government for the vocational training of 400 youth for equipment maintenance, thereby facilitating a form of human capital investment. Further CSR measures mentioned in the interviews were the donation of two "medical outreach vehicles," classroom renovations, a sponsorship program for students, the establishment of Early Childhood Development Centers, food donations to local schools, and water-trucking during extremely dry seasons.

Overall, there is no public or clear information on CSR measures in Baringo-Silali or on their implementation status. Meanwhile, the local communities have developed their own ways to deal with the challenges and opportunities provided by the GDC.

\subsection{Community Responses and Local Practices}

As with much of Northern Kenya, Baringo is a difficult area for investors, not only due to the lack of basic infrastructure but also for security reasons (Lind, 2017). For decades, the area has been conflict-ridden, with automatic weapons being widely available (Mkutu, 2007). Disguised as traditional cattle raids, assaults on neighbouring communities are increasingly used to achieve political goals, and more recently the police and army have also become involved and suffered losses (Greiner, 2013). Since the Kenyan state never managed to establish its monopoly on violence in the area, the GDC-like other investors-is vulnerable and has to negotiate their presence with care (Greiner, 2020).

To express their grievances to the GDC, local communities have resorted to roadblocks. Often symbolic in nature, these consist of a few stones or branches, but in the context of the general insecurity, they have proved an effective means to enter into negotiation over the nonpayment of salaries by contractors or the lack of water in CWPs. As roadblocks can become a serious problem for work schedules and sometimes also for the workers' safety, the GDC is usually keen on dealing with these issues quickly, though solutions are often short-term or postponed nonetheless (especially regarding payments from contractors). There are also cases in which GDC vehicles simply take alternative routes to the project sites to avoid such roadblocks. Roadblocks can be initiated by individuals (mostly regarding non-payment), but also together with elders (especially regarding lack of water at schools) or youths (regarding lack of employment). There are also other cases of 'ad-hoc negotiation' during construction, e.g., welders were forced to weld holes in pipes so that a leak could occur through which locals could get water (information provided in this and the following paragraph was gathered and cross-checked in several community and expert interviews, 2018-2020). 
While the GDC and the water point committees try to sensitize communities about the intended use of water, unauthorized usage and consumption of unfiltered water are a major problem. Leakages and breakages of pipelines are common and people tend to use the closest water source available, sometimes waiting hours to have water pumped at frequent leakage points. Vandalism, e.g., tampering with pressure-relief valves or cutting the five-inch community pipelines, frequently happens along remote pipelines. Since maintenance by contractors or GDC staff can be slow, people also try to fix community pipelines with ropes or stones, although such makeshift fixes usually cannot handle the pressure for long and have even been destroyed by baboons looking for water (interviews and observation in February 2020). Apart from human and animal consumption, leakage and overflows of livestock water points are also used for farming activities.

Despite the implementation of CWPs, the local population still perceives water as a significant issue and complains, for example, that livestock water points are insufficient for the number of livestock in the area. Apart from more water points, the communities also demand greater employment opportunities and other benefits. Whether the recent striking of steam in Paka will lead to more CSR measures is an open question right now. Notwithstanding, and partly due to the threat of armed violence and resistance, community responses figure highly in the GDC's strategy. This provides a good example of how local communities can-to some extent"alter the parameters of subsequent action" (Hay, 1997, p. 51) and influence the investor and its strategies. As has been shown, $\mathrm{KfW}$ as the international funder is also a player in this context, and is trying to protect its reputation by ensuring adequate consideration of and adherence to environmental and social standards. This demonstrates the importance of cross-scale linkages in geothermal development and the associated investorcommunity relations.

\section{Summary and Conclusion}

Geothermal development for centralized electricity generation is still in the exploration and drilling stage in Baringo-Silali. Even in this early stage, its implementation and governance are much more complex than topdown, with various cross-scale linkages ranging from the local community shaping context conditions for GDC activities on the ground to the international funder $\mathrm{KfW}$ with its impact on ESIA and CSR measures. The resulting types of multilevel governance in geothermal development in Kenya include institutional interplay, comanagement, and the GDC as bridging organization. Our case study also shows that centralized electricity generation can, as with de-centralized electricity systems, have strong local impacts, with local communities playing an active part.

The legal situation in Kenya with its progressive new constitution and environmental legislation, the new
Community Land Act and royalty-sharing rules, as well as recent devolution, play an important role in enabling and enforcing cross-scale linkages and multilevel governance. As of now, the county level seems to be less important in geothermal development in Baringo-Silali. This, however, might change with the ongoing implementation of devolution and the progress of geothermal development. While there is evidence that devolution did not dismantle, but rather restructured patronage and rent-seeking in Kenya (D'Arcy \& Cornell, 2016), it would be premature to draw conclusions about the county's role regarding geothermal energy infrastructure. This also due to the fact that the regulating Energy Act has only recently been issued (in 2019) and the project is still in its infancy. Most significant, however, is the fact that no royalties have yet been distributed, which could lead to irregularities and conflicting claims. As soon as centralized electricity generation is established in Baringo-Silali, the county receives $20 \%$ of the royalties, which could, for example, be used to provide connections to the national grid. Starting electricity generation will also involve new actors such as IPPs and climate finance organizations, thereby making governance structures more complex and international and strengthening cross-scale linkages through further requirements regarding sustainability and community benefits.

Regarding sustainability and local impacts, how-and whether-geothermal development in Baringo-Silali will benefit the local population will depend to a certain extent on the GDC and its management of investorcommunity relations. So far, it is hard to say whether community engagement and impact assessments are "more about improving legitimacy rather than benefitting local communities" (Sovacool \& Cooper, 2013, p. 241). The community in Baringo, however, is not a passive recipient of benefits; rather it actively engages in negotiations as well as in acts of resistance and sabotage if important demands are not met or GDC activities are regarded as unfair. Community action and responses, therefore, have the potential to disrupt project advancement, not only in technical terms, e.g., through roadblocks, but also through legal and political action along cross-scale linkages, as has already happened in Olkaria. Up to now, we could not observe interventions by NGOs and CSOs in these matters. Therefore, the extent to which greater private, international, and civil-society participation would benefit the community remains an open question. This is one among many questions that certainly require further research into the future development of geothermal development in Baringo.

In conclusion, this case study has demonstrated that cross-scale linkages need to be considered to understand how power relations impact the implementation and governance of large-scale electricity generation and in associated investor-community relations. To analyze actor and governance constellations, we applied a concept of cross-scale linkages from research on socio-ecological systems. While the original concept mainly refers to the 
interactions between state actors and communities, we have adapted and used it for a wider group of actors, also including parastatals, companies, and international agencies. This has revealed the limits of this approach with its focus on institutional interplay, co-management, and bridging organizations, which can only partly reflect the complexities of large-scale energy projects with a multitude of state, community, private, and international actors, as well as their various competing interests and accountabilities.

\section{Acknowledgments}

We thank our interviewees for sharing their knowledge and experiences with us. We are also grateful to the editors of this thematic issue and to two anonymous reviewers who pointed to critical issues and helped to expand the scope of the article. This research was supported by the German Research Foundation through funding for the project "Energy futures" as part of the Collaborative Research Center "Future Rural Africa" (Project-ID 328966760-TRR 228).

\section{Conflict of Interests}

The authors declare no conflict of interests.

\section{References}

Alanne, K., \& Saari, A. (2006). Distributed energy generation and sustainable development. Renewable and Sustainable Energy Reviews, 10(6), 539-558.

Alstone, P., Gershenson, D., \& Kammen, D. M. (2015). Decentralized energy systems for clean electricity access. Nature Climate Change, 5(4), 305-314.

Anderson, D. M., \& Bollig, M. (2016). Resilience and collapse: Histories, ecologies, conflicts and identities in the Baringo-Bogoria basin, Kenya. Journal of Eastern African Studies, 10(1), 1-20.

Baringo County Government. (2014). Annual development plan 2015/16. Baringo County: Baringo County Government. Retrieved from https://devolutionhub. or.ke/file/402f0a5d7b572be235d272e5e01f7f5e.pdf

Berkes, F. (2002). Cross-scale institutional linkages: Perspectives from the bottom up. In E. Ostrom, T. Dietz, N. Dolšak, P.C. Stern, S. Stonich, \& E. U. Weber (Eds.), The drama of the commons (pp. 293-321). Washington, DC: National Academy Press.

Boamah, F. (2020). Desirable or debatable? Putting Africa's decentralised solar energy futures in context. Energy Research \& Social Science, 62, 101390.

Boliko, C. M., \& lalnazov, D. S. (2019). An assessment of rural electrification projects in Kenya using a sustainability framework. Energy Policy, 133. https://doi. org/10.1016/j.enpol.2019.110928

Bollig, M. (2016). Adaptive cycles in the savannah: Pastoral specialization and diversification in northern Kenya. Journal of Eastern African Studies, 10(1), 21-44.
Bollig, M., Greiner, C., \& Österle, M. (2014). Inscribing identity and agency on the landscape: Of pathways, places, and the transition of the public sphere in East Pokot, Kenya. African Studies Review, 57(3), 55-78.

Bouffard, F., \& Kirschen, D. S. (2008). Centralised and distributed electricity systems. Energy Policy, 36(12), 4504-4508.

Cash, D. W., Adger, W. N., Berkes, F., Garden, P., Lebel, L., Olsson, P., . . . \& Young, O. (2006). Scale and cross-scale dynamics: Governance and information in a multilevel world. Ecology and Society, 11(2). Retrieved from http://www.ecologyandsociety.org/ vol11/iss2/art8

D’Arcy, M., \& Cornell, A. (2016). Devolution and corruption in Kenya: Everyone's turn to eat? African Affairs, 115(459), 246-273.

Eberhard, A., Gratwick, K., Morella, E., \& Antmann, P. (2016). Independent power projects in Sub-Saharan Africa: Lessons from five key countries. Washington, DC: World Bank Group. https://doi.org/10.1596/9781-4648-0800-5

Enns, C. (2016). Experiments in governance and citizenship in Kenya's resource frontier (Unpublished Doctoral dissertation). University of Waterloo, Kitchener, Canada. Retrieved from https://core.ac.uk/ download/pdf/144149828.pdf

Geothermal Development Corporation. (2019). Steam field exploration in Baringo County shapes up. Geothermal Development Company. Retrieved from http://www.gdc.co.ke/blog/steam-field-explorationin-baringo-county-shapes-up

Geothermal Development Corporation. (n.d.a). Menengai project. Geothermal Development Company. Retrieved from https://www.gdc.co.ke/menengai.php

Geothermal Development Corporation. (n.d.b). BaringoSilali project. Geothermal Development Company. Retrieved from https://www.gdc.co.ke/baringo.php

Government of Kenya. (2007). Kenya Vision 2030: The popular version. Nairobi: Republic of Kenya. Retrieved from http://vision2030.go.ke/inc/uploads/ 2018/05/Vision-2030-Popular-Version.pdf

Greiner, C. (2013). Guns, land and votes: Cattle rustling and the politics of boundary-(re)making in Northern Kenya. African Affairs, 112(447), 216-237.

Greiner, C. (2017). Pastoralism and land tenure change in Kenya: The failure of customary institutions. Development and Change, 48(1), 78-97.

Greiner, C. (2020). Negotiating access to land \& resources at the geothermal frontier in Baringo, Kenya. In J. Lind, D. Okenwa, \& I. Scoones (Eds.), Land, investment \& politics: Reconfiguring Eastern Africa's pastoral drylands (pp. 101-109). Woodbridge: James Currey.

Harvey, P., Jensen, C. B., \& Morita, A. (2017). Introduction: Infrastructural complications. In P. Harvey, C. B. Jensen, \& A. Morita (Eds.), Infrastructures and social complexity: A companion (pp. 1-22). London: Routledge. 
Hay, C. (1997). Divided by a common language: Political theory and the concept of power. Politics, 17(1), 45-52.

Hooghe, L., \& Marks, G. (2003). Unraveling the central state, but how? Types of multi-level governance. American Political Science Review, 97(2), 233-243.

Hughes, L., \& Rogei, D. (2020). Feeling the heat: Responses to geothermal development in Kenya's Rift Valley. Journal of Eastern African Studies, 14(2), 165-184.

Hughes, T. P. (1983). Networks of power: Electrification in Western society, 1880-1930. Baltimore, MD: John Hopkins University Press.

International Energy Agency. (2020). Data and statistics. International Energy Agency. Retrieved from www. iea.org/statistics

KfW Development Bank. (2019). Sustainability guideline. Assessment and management of environmental, social, and climate aspects: Principles and procedures. Frankfurt a.M.: KfW Development Bank. Retrieved from https://www.kfw-entwicklungsbank.de/PDF/ Download-Center/PDF-Dokumente-Richtlinien/ Nachhaltigkeitsrichtlinie_EN.pdf

Kirubi, C., Jacobson, A., Kammen, D. M., \& Mills, A. (2009). Community-based electric micro-grids can contribute to rural development: Evidence from Kenya. World Development, 37(7), 1208-1221.

Klagge, B., \& Nweke-Eze, C. (2020). Financing largescale renewable-energy projects in Kenya: Investor types, international connections, and financialization. Geografiska Annaler: Series B, Human Geography, 102(1), 61-83.

Koissaba, B. R. O. (2018). The Olkaria projects: A case study of geothermal energy and indigenous communities in Kenya. Brussels: Heinrich Boell Stiftung. Retrieved from https://eu.boell.org/sites/ default/files/geothermal-energy-and-indigenouscommunities-olkariaproject-kenya.pdf

Li, T. M. (2005). Beyond "the state" and failed schemes. American Anthropologist, 107(3), 383-394.

Linaweaver, S. (2009). Catching the boomerang: EM, the World Bank, and excess accountability: A case study of the Bujagali Falls hydropower project Uganda. International Journal of Sustainable Development \& World Ecology, 10(4), 283-301.

Lind, J. (2017). Devolution, shifting centre-periphery relationships and conflict in northern Kenya. Political Geography, 63, 135-147.
Mangi, M. P. (2017). Geothermal exploration in Kenya: Status report and updates. Paper presented at SDG Short Course II on Exploration and Development of Geothermal Resources, Lake Bogoria and Lake Naivasha, Kenya. Retrieved from https://orkustofnun. is/gogn/unu-gtp-sc/UNU-GTP-SC-25-0701.pdf

Mariita, N. O. (2002). The impact of large-scale renewable energy development on the poor: environmental and socio-economic impact of a geothermal power plant on a poor rural community in Kenya. Energy Policy, 30(11/12), 1119-1128.

Ministry of Energy. (2018). Kenya national electrification strategy: Key highlights. Nairobi: Ministry of Energy. Retrieved from http://pubdocs.worldbank. org/en/413001554284496731/Kenya-NationalElectrification-Strategy-KNES-Key-Highlights2018.pdf

Mkutu, K. A. (2007). Small arms and light weapons among pastoral groups in the Kenya-Uganda border area. African Affairs, 106(422), 47-70.

Mwangi, O. G. (2008). Political corruption, party financing and democracy in Kenya. Journal of Modern African Studies, 46(2), 267-285.

National Environment Management Authority. (2020). Environment impact assessment (EIA). National Environment Management Authority. Retrieved from http://www.nema.go.ke/index.php?option=com content\&view=article\&id=119\&Itemid $=144$

Ostrom, E. (2005). Understanding institutional diversity. Princeton, NJ: Princeton University Press.

Republic of Kenya. (2019). Kenya gazette supplement No. 29 (Acts No. 1). Nairobi: Republic of Kenya. Retrieved from https://kplc.co.ke/img/full/o8wccHsFPaZ3_ ENERGY\%20ACT\%202019.pdf

Schade, J. (2017). Kenya "Olkaria IV" case study report: Human rights analysis of the resettlement process (Working Papers-Centre on Migration, Citizenship and Development No. 151). Bielefeld: COMCAD.

Scott, J. C. (1998). Seeing like a state: How certain schemes to improve the human condition have failed. New Haven, CT: Yale University Press.

Sovacool, B. K., \& Cooper, C. J. (2013). The governance of energy megaprojects: Politics, hubris and energy security. Cheltenham and Northampton, MA: Edward Elgar.

Wynne, B. (1988). Unruly technology: Practical rules, impractical discourses and public understanding. Social Studies of Science, 18(1), 147-167.

\section{About the Authors}

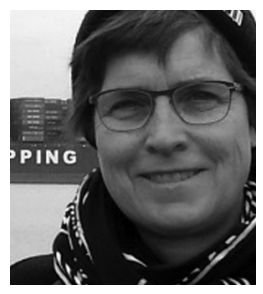

Britta Klagge is Professor of Geography and Head of the Department of Geosciences at the University of Bonn, Germany. Her current research focuses on economic geography with a special interest in energy research, finance, globalization, and governance. Together with Clemens Greiner, she leads the "Energy Futures" project on geothermal development in Baringo, which is part of the Collaborative Research Center "Future Rural Africa" (www.crc228.de). 


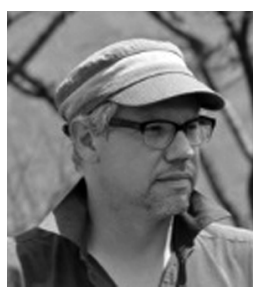

Clemens Greiner is a Social and Cultural Anthropologist and the Academic Coordinator of the Global South Studies Center at the University of Cologne. His research focuses on political ecology, translocality, infrastructure, and the transformation of pastoralism in Eastern and Southern Africa. Together with Britta Klagge, he leads the "Energy Futures" project on geothermal development in Baringo, which is part of the Collaborative Research Center "Future Rural Africa" (www.crc228.de).

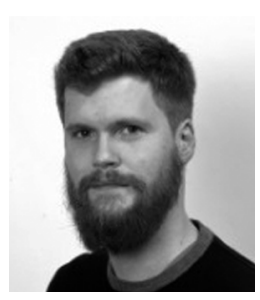

David Greven is currently doing a PhD in Anthropology at the University of Cologne. His research focus is on the impacts of large-scale development projects on pastoral livelihoods in Kenya. He is also part of the "Energy Futures" project on geothermal development in Baringo, which is part of the Collaborative Research Center "Future Rural Africa" (www.crc228.de).

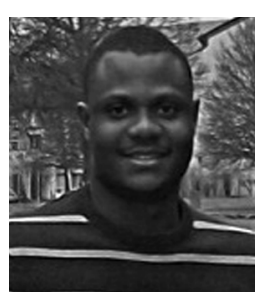

Chigozie Nweke-Eze is a PhD Student at the Institute of Geography, University of Bonn. For his doctoral thesis, he is researching the financing, governance, and infrastructure of large-scale renewable energy projects in the Kenyan peripheries. He is a Research Associate in the "Energy Futures" project, which is part of the Collaborative Research Center "Future Rural Africa" (www.crc228.de). 